\title{
Wojna w Iraku w Świetle Doktryny Busha
}

PORY I KONFLIKTY MIĘDZYNARODOWE UCHODZĄ ZA JEDEN Z NAJBARDZIEJ dys-
funkcjonalnych czynników współczesnych stosunków międzynarodowych. Pomimo starań ONZ (Organizacji Narodów Zjednoczonych) i innych organizacji dążących do stabilizacji środowiska międzynarodowego nie udało się wyrugować wojny z instrumentów realizacji polityki zagranicznej. Jest to tym bardziej zaskakujące, że państwa deklarujące przywiązanie do pokoju same sięgają po instrumenty militarne. Odzwierciedleniem tego założenia pozostaje doktryna Busha ${ }^{2}$. Pomimo idealistycznego przesłania, realizacja jej założeń doprowadziła do wybuchu największego konfliktu początku XXI w⿳3.

${ }^{1}$ Artykuł dotyczy wojny w Iraku, rozpoczętej atakiem sił koalicji międzynarodowej, której trzon stanowiły wojska amerykańskie, brytyjskie, australijskie i polskie na Irak 20 marca 2003 r. Głównym celem wojsk koalicji było odsunięcie od władzy prezydenta Saddama Husajna. 1 maja 2003 r. prezydent USA George W. Bush ogłosił oficjalne zakończenie działań wojennych, rozpoczynając tym samym proces okupacji, trwający do czerwca 2004 r., kiedy przekazano władzę tymczasowemu rządowi. Bezpośrednio po inwazji koalicja została rozszerzona do kilkudziesięciu państw. Wraz z rozwojem sytuacji w Iraku, kolejne państwa wycofywały jednak swoje siły. Wojska amerykańskie zostały wycofane w grudniu 2011 r., niemniej proces ten rozpoczął się znacznie wcześniej, stopniowo przekazując odpowiedzialność za sytuację w kraju rządowi i armii irackiej.

${ }^{2}$ Pojęcie doktryny wywodzi się z języka łacińskiego, gdzie oznaczała naukę lub wiedzę. Współcześnie jej rozumienie jest bardziej zróżnicowane. Zważywszy na przedmiot zainteresowania poniższej pracy, termin doktryny będzie rozumiany w odniesieniu do stosunków międzynarodowych. Doktryna Busha w tym ujęciu oznacza zatem główne wytyczne polityki zagranicznej Stanów Zjednoczonych Ameryki (co do celów, czasu, miejsca, metod i środków realizacji), którymi kierowała się administracja Georga Walkera Busha.

${ }^{3}$ Przy tym stwierdzeniu można posłużyć się rozmaitymi przesłankami np. liczbą ofiar, długością konfliktu, rodzajem zastosowanej broni czy też poniesionymi kosztami. Według portalu Iraq body count liczba ofiar przemocy w Iraku od czasu inwazji do końca stycznia 2016 r. po stronie irackiej wynosi od 151,912 - 171,760 (Iraq body count). Przy czym warto podkreślić, że są to tylko ofiary udokumentowane wśród samej ludności cywilnej, łącznie z kombatantami liczba ofiar rośnie do 242 tysięcy osób. Również koszty ekonomiczne wskazują na skalę konfliktu. Według wyliczeń amerykańskich ekonomistów całkowity koszt wojny w Iraku, poniesiony przez same tylko Stany Zjednoczone miałby przekroczyć 3 biliony dolarów (Stiglitz, Bilmes, 2010, s. 27). Biorąc pod uwagę te czynniki oraz zastosowanie na masową skalę broni inteligentnej można określić 
Praca bazuje na hipotezie, że doktryna Georga W. Busha, stanowiąca podstawę bliskowschodniej polityki Stanów Zjednoczonych w okresie jego prezydentury, doprowadziła do amerykańskiej inwazji na Irak w 2003 r., a deklarowane przyczyny interwencji zbrojnej nie pokrywały się z rzeczywistymi. W efekcie realizacji doktryny doszło do strat (materialnych i niematerialnych), na które Stany Zjednoczone, ani społeczność międzynarodowa nie były przygotowane. Z punktu widzenia metodologii największą rolę odegrała pogłębiona analiza materiałów źródłowych, tj. dokumentów, raportów oraz oficjalnych wystąpień prezydenta G. W. Busha i innych amerykańskich polityków, którzy mieli bezpośredni wpływ na jego decyzje.

Celem poniższego artykułu jest analiza przyczyn i ocena wojny w Iraku z perspektywy polityki zagranicznej ostatniego republikańskiego prezydenta Stanów Zjednoczonych. Problem wojny w Iraku jest bardzo popularny w literaturze przedmiotu, szczególnie dotyczy to literatury anglosaskiej, niemniej jest też często poruszany w literaturze polskiej. Obszerne badania nad przyczynami tego konfliktu przedstawił Hubert Świętek, w pracy „Wojna z Irakiem w 2003 r. Główne przyczyny”. Na uwagę zasługują również prace Wojciecha Szymborskiego p.t. „Doktryna Busha” oraz „Irak. Dylematy amerykańskiej interwencji” pod redakcją Witolda Dzielskiego i Wojciecha Michnika. Z punktu widzenia pracy najwyższy walor użyteczności posiadają przemówienia G. W. Busha, zwłaszcza ich fragmenty poświęcone sytuacji na Bliskim Wschodzie, a także Strategie Bezpieczeństwa Narodowego z 2002 i 2006 r. Okazuje się, że te przyczyny na które pierwotnie powoływała się administracja prezydenta G. W. Busha nie wytrzymują próby czasu. $\mathrm{Z}$ perspektywy kilkunastu lat od interwencji można stwierdzić, że rzeczywiste przyczyny amerykańskiej inwazji na Irak różnią się od deklarowanych, które dziś można łatwo zanegować. Analizując materiał badawczy skupiono się na kilku kluczowych pytaniach badawczych:

- Jakie zagrożenia dostrzegano ze strony Iraku?

- Czy zagrożenia te były realne?

- Jak poczucie zagrożenia przełożyło się na interwencję wojskową USA w Iraku?

- Jaki wpływ miało otoczenie Busha na jego decyzję o interwencji wojskowej?

wojnę w Iraku największym konfliktem zbrojnym pierwszej dekady XXI wieku. Według kryterium czasu, obecność Amerykanów, trwała nieco ponad 8 i pół roku, podczas gdy w Afganistanie ponad 13 lat. W rzeczywistości trudno jednak w obu przypadkach mówić o zakończeniu wojny, ponieważ w obu państwach ma miejsce wojna domowa. 
- Jaki wpływ miała interwencja w Iraku na postrzeganie USA w świecie?

Podjęty temat jest bardzo złożony i wielowątkowy, ponieważ jego wnikliwa analiza wymaga odwołania się do zróżnicowanych uwarunkowań. Dostępność materiałów źródłowych i opracowań naukowych daje możliwość prowadzenia wnikliwych badań, jednak szczegółowa analiza przekracza ramy artykułu, który stanowi tylko sygnalizację pewnych kwestii. Za punkt wyjścia do dalszych rozważań przyjęto krótkie omówienie podstaw polityki bliskowschodniej Stanów Zjednoczonych w ujęciu historycznym.

\section{FILARY BLISKOWSCHODNIEJ POLITYKI STANÓW ZJEDNOCZONYCH}

BLISKI WSCHÓD OD DAWNA STANOWIŁ MIEJSCE RYWALIZACJI MOCARSTW I DO DZIŚ pozostaje jednym z najistotniejszych regionów geopolitycznych we współczesnym świecie. Charakteryzując główne założenia amerykańskiej polityki zagranicznej należy się odwołać do najważniejszych koncepcji strategicznych w ujęciu historycznym, sięgając do pierwszej połowy XIX w. Warto jednak mieć na uwadze, iż w centrum zainteresowania polityki amerykańskiej Bliski Wschód znalazł się dopiero w połowie XX w. Odpowiadają za to złożone przyczyny. Pierwszą i najistotniejszą jest izolacjonizm utrzymujący się do II wojny światowej. Deklaracja amerykańskiego prezydenta Jamesa Monroe z 1823 r. stanowiła potwierdzenie tendencji izolacjonistycznych i o ile wówczas miało to swoje uzasadnienie we względnej słabości nowo powstałego państwa, to powrót USA do izolacjonizmu po 1919 r. był wynikiem przewagi sił izolacjonistycznych i osobistą porażką prezydenta Thomasa Woodrowa Wilsona. Dopiero rezultat II wojny światowej wymusił na ówczesnym prezydencie Stanów Zjednoczonych Harrym Trumanie ostateczne zerwanie z izolacjonizmem. Od 1945 r. do końca lat 70. XX w. amerykańska polityka względem regionu opierała się na zasadzie tzw. równowagi poza granicami (offshore balancing), sprowadzającej się do braku bezpośredniego zaangażowania. (Michnik, 2007, s. 101). Potwierdzeniem globalnych aspiracji USA pozostaje ogłoszona w marcu 1947 r. doktryna H. Trumana, będąca pierwszym znaczącym wystąpieniem amerykańskiego prezydenta w historii, podkreślającego rangę Bliskiego Wschodu w polityce USA. Moment opublikowania doktryny stanowiło jednocześnie symboliczne przejęcie odpowiedzialności od Brytyjczyków za stabilność w regionie.

Kolejnym etapem w rozwoju koncepcji amerykańskiej polityki względem regionu była doktryna Eisenhowera. Republikański pre- 
zydent reagując na kryzys sueski potwierdził gotowość pomocy państwom Bliskiego Wschodu zagrożonym przez komunizm (Eisenhower, Special, 1957). Doktryna Eisenhowera była częścią zimnowojennej rywalizacji, a jednocześnie wskazywała na coraz wyraźniejsze zainteresowanie przez USA sytuacją na Bliskim Wschodzie, jej efektem była amerykańska interwencja w Libanie w 1958 r.

W latach 70. XX w. Stany Zjednoczone realizowały swoją politykę w regionie poprzez tzw. doktrynę dwóch bliźniaczych filarów. Filarami polityki bliskowschodniej pozostawały więc dwa największe terytorialnie, proamerykańskie państwa zasobne w ropę naftową, czyli Iran i Arabia Saudyjska (Rathmell, Karasik, Gompert). Koniec lat 70. XX w. i wydarzenia z tym związane (interwencja ZSRR w Afganistanie, rewolucja islamska w Iranie i przejęcie władzy przez Saddama Husajna w Iraku) zmusiły Stany Zjednoczone do zmiany polityki zagranicznej. Przyjęte wówczas założenia w kontekście Bliskiego Wschodu pozostają aktualne do dziś.

Przyjęta w 1980 r. doktryna Jamesa Cartera stanowiła wyraźne potwierdzenie amerykańskich interesów w regionie. Uznano, iż jakakolwiek próba ingerencji sił z zewnątrz spotka się z reakcją, także militarną ze strony Stanów Zjednoczonych: ,jakakolwiek próba przejęcia kontroli nad regionem Zatoki Perskiej przez siły zewnętrzne będzie uznana za atak na żywotne interesy Stanów Zjednoczonych Ameryki i taki atak będzie odparty przy użyciu wszelkich niezbędnych środków, także przy użyciu siły militarnej” (Carter, 1980). Realizacja założeń zaowocowała zwiększeniem się obecności sił amerykańskich na Bliskim Wschodzie. Wymowa doktryny jest przy tym bardziej zrozumiała po uwzględnieniu znaczenia strategicznego Bliskiego Wschodu. Pomimo intensywnego wydobycia złoża zlokalizowane na Bliskim Wschodzie w dalszym ciągu stanowią prawie 48\% światowych zasobów (BP statistical, 2015).

Lata 80. XX w. zdominowała wojna między Irakiem a Iranem, co z jednej strony przyczyniło się do eskalacji napięć w regionie, a z drugiej do niejednoznacznej polityki samych Stanów Zjednoczonych. Administracja amerykańska formalnie nie udzielała wsparcia żadnej ze stron, jednak w rzeczywistości czynnie pomagała Irakowi jednocześnie sprzedając broń do Iranu i pozyskując w ten sposób fundusze na finansowanie partyzantki w Nikaragui - afera Iran-Contras. 


\section{BLISKOWSCHODNIA POLITYKA USA PO ZIMNEJ WOJNIE}

Po Zajęciu Kuwejtu przez IraK w 1990 R. Stany ZJednoczone Stanowiey trzon antyirackiej koalicji. Bezdyskusyjne zwycięstwo w tej ograniczonej co do skali operacji przyniosło ze sobą inne skutki niż tylko samo wyzwolenie Kuwejtu. Ograniczono import irackiej ropy, zobowiązano państwo irackie do wypłacenia Kuwejtowi odszkodowania oraz dokonano częściowego rozbrojenia, przede wszystkim zmuszając Irak do zniszczenia broni chemicznej. Uderzono zatem w ekonomiczne i militarne podstawy władzy S. Husajna.

Z punktu widzenia analizy polityki amerykańskiej o wiele istotniejsze zdają się być okoliczności w jakich znalazły się Stany Zjednoczone. Po pierwsze udało się uzyskać zgodę Rady Bezpieczeństwa ONZ na interwencję, dzięki czemu nikt nie podważał jej legalności. Po drugie umiejętność zbudowania szerokiej koalicji, w której składzie znalazły się także państwa muzułmańskie stanowiła olbrzymi sukces administracji G. H Busha. Po trzecie skala zwycięstwa nie pozostawiała wątpliwości, że Stany Zjednoczone pozostają najpotężniejszym państwem świata $\mathrm{w}$ pozimnowojennej rzeczywistości. Można zatem przyjąć założenie, że bezpośrednio po upadku ZSRR Stany Zjednoczone miały wszystkie atrybuty do odgrywania roli światowego przywódcy.

Administracja Wiliama J. Clintona odziedziczyła „problem iracki” po G. H. Bushu. Jej polityka bliskowschodnia stanowiła przeplatanie się sukcesów z dotkliwymi porażkami. Pomimo, iż za największą porażkę w regionie można uznać impas w bliskowschodnim procesie pokojowym, to również w przypadku Iraku USA wykazywało niezdecydowanie. Amerykanie nie przystąpili do otwartej interwencji, niemniej udało się im skutecznie zniechęcić Irak do rozbudowy potencjału militarnego (Szymborski, 2004, s. 62). Coraz większa aktywność organizacji terrorystycznej Al-Kaida wymuszała na Stanach Zjednoczonych ciągłe modyfikowanie założeń bliskowschodniej polityki zagranicznej. Jednak prawdziwy przełom w polityce USA nastąpił dopiero w $2001 \mathrm{r}$.

\section{PrZEŁOM 2001 R.}

PEene KontrowersJI WYBory PREZYDENCKIE Z 2000 R. PRZYNIOSŁY Zwycięstwo kandydatowi Republikanów Georgowi W. Bushowi. Zwycięstwo tego kandydata oznaczało jednak nie tylko powrót po ośmiu latach do władzy Republikanów. Nowy prezydent dobierając sobie najważniejszych współpracowników decydował się na osoby zajmujące ważne stanowiska w administracji jego ojca np. Richard Cheney, lub też blisko z tą administracją związane np. Donald Rumsfeld. Ogromne 
doświadczenie polityczne współpracowników prezydenta przy jego relatywnie słabym przygotowaniu do sprawowania urzędu wpływało na kształt polityki zagranicznej USA. Początki prezydentury przebiegały jednak spokojnie i do czasu zamachu nic nie zapowiadało zwrotu w polityce zagranicznej.

Atak na WTC (World Trade Center - Światowe Centrum Handlu) pozostaje momentem przełomowym w dziejach. Często porównuje się go do ataku na Pearl Harbor. Po raz pierwszy od pięćdziesięciu kilku lat zaatakowano najpotężniejsze państwo świata na jego własnym terytorium. Okazało się, że Stany Zjednoczone nie są wcale bezpieczne. Początkowa reakcja zdawała się wskazywać na pośpiech administracji Busha. Szukano winnych zamachów, choć niemal od pierwszej chwili wskazywano na Osamę bin Ladena i kierowaną przez niego Al-kaidę. Nie wypełniając żądań USA odnośnie wydania O. bin Ladena Afganistan sprowokował amerykańską interwencję $\mathrm{w}$ ramach operacji „Trwała Wolność”. Bezpośrednim skutkiem zamachów na WTC pozostaje zatem wojna w Afganistanie, pierwsza wojna XXI w. (Malendowski, 2006, s. 311). Biorąc pod uwagę postawę społeczności międzynarodowej względem ofiar zamachów okazało się, że sama interwencja spotkała się z aprobatą ze strony większości państw, które albo deklarowały neutralność, albo same przyłączały się do operacji

\section{ZAŁOŻENIA DOKTRYNY BUSHA}

ŹRÓDEE DOKTRYNY BUSHA NALEŻY UPATRYWAĆ W CZTERECH WYSTĄPIENIACH amerykańskiego prezydenta, tj. przemówienia z 11 września 2001 r., 20 września 2001 r., orędzia o stanie państwa z 29 stycznia 2002 r., a także przemówienia wygłoszonego na Akademii Wojskowej West Point 20 czerwca 2002 r. oraz w ogłoszonych w 2002 i 2006 r. Strategiach Bezpieczeństwa Narodowego. Główne przesłanie koncentrowało się wokół trzech zasadniczych elementów:

- wojna z terroryzmem

- oś zła

- uderzenie wyprzedzające i wojna prewencyjna (Troszyńska, 2006, s. $62-75)^{4}$.

Podstawowe założenia znalazły się już w przemówieniu G. W. Busha, wygłoszonym 11 września 2001 r. Zaakcentowano w nim siłę Sta-

${ }^{4}$ Nieco inaczej filary doktryny Busha wyznaczył Wojciech Szymborski, według niego filarami tymi były wojna $\mathrm{z}$ terrorem, prawo do działań prewencyjnych oraz odrzucenie moralnego relatywizmu (Szymborski, 2004, s. 81). 
nów Zjednoczonych: „ataki terrorystów mogą wstrząsnąc fundamentami naszych największych budynków, ale nie wzruszą fundamentów Ameryki”. Pojawiła się zapowiedź odwetu: „Dziś nasz naród zobaczył zło - najgorszą naturę człowieka - i odpowiemy na nie najlepiej jak Ameryka potrafi”. Jednocześnie, już wtedy, idealizm typowy dla wielu amerykańskich wystąpień przeplatał się ze skłonnością do stosowania siły: „Ameryka i nasi przyjaciele oraz sojusznicy łączą się i stają razem z każdym, kto chce pokojowego oraz bezpiecznego świata do zwycięskiej wojny przeciwko terroryzmowi” (Bush, 2001).

Główne tezy wystąpienia zostały rozszerzone w przemówieniu z 20 września $2001 \mathrm{r}$. W przemówieniu wyraźnie podkreślono cel, jakim była ostateczna likwidacja terroryzmu jako metody walki: „Nasza wojna z terroryzmem zaczyna się od Al-Kaidy, ale na niej się nie kończy. Nie skończy się dopóty, dopóki każda grupa terrorystów o światowym zasięgu nie zostanie odszukana, powstrzymana i pokonana”. Wojna z terroryzmem miała więc wymiar globalny, a zwycięstwo w niej miało wymagać od Ameryki ofiar. Prezydent podkreślił odmienność tej wojny od tradycyjnie rozumianych konfliktów zbrojnych, wskazując jednocześnie na wynikające z wojny ograniczonej koszty: „Ta wojna nie będzie przypominać wojny z Irakiem sprzed dziesięciu lat, która miała szybkie zakończenie i doprowadziła do całkowitego wyzwolenia pewnego terytorium (...) Nasza reakcja nie może polegać jedynie na szybkim odwecie i izolowanych uderzeniach wojskowych. Amerykanie powinni się spodziewać nie jednej bitwy, lecz długiej kampanii, niepodobnej do żadnej poprzedniej”. znaczył, iż nie utożsamia islamu z terroryzmem: „Terroryści wyznają marginesową formę skrajnego islamizmu, którą odrzuciła większość muzułmańskich teologów i duchownych. To margines, który wypacza pokojowe nauczanie islamu" (Bush, Przemówienie).

Charakterystyczną cechą przesłania doktryny był wyraźny podział na świat dobra reprezentowanego przez Stany Zjednoczone, jak i zła, utożsamianego z przeciwnikami Stanów Zjednoczonych. Świadczy to o postrzeganiu wojny w kategoriach moralnych i w swoich działaniach Stany Zjednoczone miały kierować się względami moralnymi. W oficjalnych komunikatach przedstawiano misję Stanów Zjednoczonych jako przykład bezinteresowności, walki o ogólnie aprobowane

${ }^{5}$ Podobny charakter miało prezydenckie wystąpienie z 1.06.2002 r. na Akademii West Point. W podniosłym przemówieniu G. W. Bush podkreślił rolę Stanów Zjednoczonych w walce o pokój oraz wskazywał na koszty wojny z terroryzmem podkreślając jednocześnie, że wojna ta nie może ograniczać się do działań defensywnych. (Bush, 2002). 
wartości takie jak wolność, demokracja i prawa człowieka. W rzeczywistości wyrazista wymowa i nacechowana wrogością retoryka świadczyła o świadomości swojej siły, jak i wyraźnej tendencji do unilateralizmu. Negowano potrzebę dialogu i wielostronnych działań w imię amerykańskiej potęgi i interesów ${ }^{6}$.

Drugim elementem doktryny pozostawała grupa tzw. osi zła (axis of evil). Oś zła miała oznaczać nie tylko organizacje terrorystyczne, ale również państwa finansujące terroryzm. Oś zła w retoryce amerykańskiego prezydenta pojawiła się w tekście Orędzia o stanie państwa, wygłoszonym 29 stycznia $2002 \mathrm{r}$. W przemówieniu prezydent G. W. Bush wskazał na te państwa, które stanowiły centrum osi zła: „Państwa takie jak te [tj. Irak, Iran, Korea Północna - przyp. P.K.] i ich terrorystyczni sprzymierzeńcy tworzą oś zła, zbrojąc się zagrażają pokojowi na świecie. Dążąc do zdobycia broni masowego rażenia stają się coraz bardziej niebezpieczne. Mogą dostarczać tę broń terrorystom dając im narzędzie do wykorzystania ich nienawiści. Mogą zaatakować naszych sojuszników, lub szantażować Stany Zjednoczone. W każdym przypadku ceną obojętności może być katastrofa" (Bush, 2002).

Oś zła była rozwinięciem koncepcji państw łotrowskich (rogue states), którymi posługiwała się administracja W. Clintona na określenie państw finansujących terroryzm, nieprzestrzegających praw człowieka i dążących do pozyskania broni masowego rażenia. Administracja prezydenta Busha nadała jednak tej idei nową wymowę, uzasadniając nią swoją politykę zagraniczną. Oś zła oprócz trzech powyższych pastw została uzupełniona o Syrię, Libię oraz Kubę (US expands, 2002). Nie sposób pominąć faktu, iż na liście znalazły się państwa sprzeciwiające się polityce Stanów Zjednoczonych, a nie znalazł się na niej chociażby Izrael, dysponujący bronią masowego rażenia i niesprzęgający praw Palestyńczyków.

Słabością idei osi zła pozostaje z całą pewnością brak bezpośrednich powiązań pomiędzy jej członkami. Nie znaleziono żadnych dowodów na współpracę Iraku z Koreą Północną czy z Iranem, nie mówiąc już o wspieraniu Al-kaidy. Koncepcja ta miała zatem jedynie wartość propagandową.

Ostatnim elementem doktryny pozostawała doktryna uderzenia wyprzedzającego. Idea ta umożliwia zwalczanie źródeł zagrożenia zanim będą one w stanie uderzyć na terytorium państwa. Jest to jed-

${ }^{6}$ Oczywiście postawa ta nie cechowała całego bezpośredniego otoczenia G. W. Busha. Jednym z największych zwolenników dialogu i wyważonych działań był sekretarz stanu Colin Powell. 
nak niezgodne z zapisami prawa międzynarodowego. Karta Narodów Zjednoczonych w artykule 51 dopuszcza prawo do indywidualnej i zbiorowej samoobrony, nie dopuszcza jednak wojny prewencyjnej. Stany Zjednoczone decydując się na taką formę działań zbrojnych dokonały złamania prawa międzynarodowego. Ideę wojny prewencyjnej określono wyraźnie w Strategii Bezpieczeństwa Narodowego z 2006 r.: „Jeżeli to konieczne, opierając się na zasadach samoobrony nie wykluczamy użycia siły zanim atak nastąpi, nawet jeśli nie ma pewności co do czasu i miejsca spodziewanego ataku" (The National, 2006).

$\mathrm{Z}$ puntu widzenia wymowy doktryny wyjątkowo wyrazisty był apel do innych państw, w którym oczekiwano potępienia terroryzmu: „Każdy kraj w każdym regionie świata musi teraz zdecydować: albo jesteście z nami, albo z terrorystami” (Bush, Przemówienie). Cytat ten wskazuje na emocjonalny aspekt doktryny, a zarazem odzwierciedla świadomość potęgi Stanów Zjednoczonych. Użyte sformułowanie jednak spowodowało liczną krytykę prezydenta Busha, którego oskarżano o arogancję. Zdaniem Jadwigi Kiwerskiej pozbawiło to Stany Zjednoczone szansy na odgrywanie roli wiarygodnego i odpowiedzialnego lidera światowej polityki (Kiwerska, 2013, s. 35).Warto zauważyć, że opinia ta jest popularna w literaturze. Krytycznie odnosili się do samej doktryny najwięksi eksperci w dziedzinie stosunków międzynarodowych, jak chociażby Zbigniew Brzeziński, Benjamin Barber, Henry Kissinger, Emmanuel Todd (Szymborski, 2004, s. 101-110). Wspomniany powyżej Z. Brzeziński określił politykę USA jako „demagogiczną, opartą na strachu i podsycającą strach” (Brzeziński, 2008, s. 155)7.

\section{RETORYKA ANTYIRACKA I JEJ ŹRÓDŁA}

Strategia Bezpieczeństwa Narodowego z 2002 R. Nie pozostawiąa wątpliwości, iż w dużej mierze odnosi się ona do sytuacji w jakiej stanęły Stany Zjednoczone po 11 września 2001 roku. Stany Zjednoczone przyznawały sobie prawo do interweniowania przy użyciu sił zbrojnych $\mathrm{w}$ razie zagrożenia ich bezpieczeństwa, wskazywano również na gotowość do działań jednostronnych. Znamienne jest to, że „terror” pod różnymi postaciami zostaje w dokumencie wspomniany 94 razy. „Irak” w Strategii z 2002 r. został wspomniany tylko raz, w rozdziale

${ }^{7}$ Głównymi zwolennikami doktryny Busha pozostawali neokonserwatyści. Literatura dostarcza jednak opracowania, które wnikliwie wyjaśniają decyzję o ataku na Irak, powołując się na szereg argumentów odwołujących się do idealizmu (np. Dzielski, 2007, s.63-78). 
poświęconym broni masowego rażenia. Wskazano, że Irak nabył i użył broni chemicznej przeciw Iranowi i własnym obywatelom, ale także zmierzał do pozyskania broni atomowej i biologicznej (The National, 2002). Jednak samo pominięcie Iraku w tekście Strategii nie świadczy, iż nie dostrzegano wtedy zagrożenia z jego strony, bowiem dziewięciokrotnie pojawiło się hasło państwa łotrowskie i raz reżimy łotrowskie. Z tekstu wynika jasno, że Irak został do tej grupy zaliczony. Kilka dni przed oficjalną publikacją dokumentu prezydent USA przemawiał na forum ONZ, gdzie wskazywał na zagrożenia ze strony Iraku, sygnalizując możliwą amerykańską interwencję. „Irak” pojawił się w ciągu jednego przemówienia aż 66 razy (Bush, 2002).

Druga kadencja prezydenta Busha miał już nieco inny charakter. Kluczowy dla jej zrozumienia dokument - Strategia Bezpieczeństwa Narodowego z 2006 różni się nieco od tej z 2002 r. Co prawda oba dokumenty w istocie prezentują zbliżoną treść, niemniej jak zauważyła J. Kiwerska nowszy dokument jest mniej „bojowy” (J. Kiwerska, 2010, s. 5). Jednocześnie w dokumencie wskazano na większa potrzebę działań multilateralnych, choć nie zanegowano zdolności USA do działań jednostronnych. W Strategii Bezpieczeństwa Narodowego z 2006 r. Irak został wspomniany 57 razy. Wspominano m.in. o sukcesie w postaci obalenia tyrana (Saddama Husajna), wprowadzeniu demokracji i pierwszych uczciwych wyborach. Wskazywano również na konieczność kontynuowania walk w Iraku, tłumacząc, iż stanowią one wspólnie z Afganistanem linię frontu na wojnie z terrorem. Powoływano się również na konieczność współpracy z nowym rządem irackim i siłami zbrojnymi tego państwa w zwalczaniu terroryzmu (The National, 2006).

Warto jeszcze odnieść się do kwestii irackiej z przemówienia pożegnalnego prezydenta Busha. W nim również poruszył on kwestię wojny w Iraku. W odniesieniu do tego państwa nie koncentrowano się już jednak na terrorze, tylko na transformacji państwa, od brutalnej dyktatury i wroga Ameryki do Arabskiej demokracji na Bliskim Wschodzie i przyjaciela Stanów Zjednoczonych (Bush, 2009). Mowa stanowiła niejako usprawiedliwienie polityki G. W. Busha, znalazł się tam chociażby argument wskazujący na to, ze w ciągu 7 lat od wydarzeń z 11 września USA nie doświadczyły żadnego ataku terrorystycznego. Jednocześnie prezydent pozytywnie oceniał swoją postawę wskazując na rolę Stanów Zjednoczonych w promowaniu wolności, praw czło- 
wieka i godności ludzkiej (Bush, 2009) ${ }^{8}$. Z perspektywy prezydenta i jego gabinetu zaangażowanie w Iraku wymagało poświęceń, ale było konieczne: „W świecie, w którym terroryści uzbrojeni w noże do cięcia kartonu zabili 3000 ludzi, Ameryka musiała zdecydować, czy może tolerować zaprzysięgłego wroga, który działał w wojowniczy sposób, popierał terroryzm i który (...) miał broń masowego zniszczenia (...) Było jasne dla mnie, dla członków obu partii politycznych i dla wielu przywódców na świecie, że po 11 września było to ryzyko, na które nie mogliśmy sobie pozwolić” (Guzik, 2016).

\section{DLACZEGO IRAK - PRZYCZYNY?}

INTERWENCJA WOJSKOWA W IRAKU ZNAJDOWAEA SIE JUŻ W PLANACH W. CLINtona. Demokratyczny prezydent miał jednak liczne powody ku temu, żeby nie podjąć działań zbrojnych przeciwko Irakowi. Administracja W. Clintona zdając sobie sprawę z kosztów ewentualnej interwencji nie zdecydowała się na otwarta wojnę. Amerykańska aktywność ograniczała się wtedy do reagowania na konkretne działania Iraku, czego przejawem jest chociażby operacja „Pustynny Lis”.

Sprzyjające okoliczności i nastawienie najbliższych współpracowników G. W. Busha odegrały główną rolę w rozpoczęciu działań wojennych w 2003 r. Lekceważąc prawo międzynarodowe i stanowiska innych państwa, zarówno przeciwników (Federacja Rosyjska, Chińska Republika Ludowa), jak też sojuszników (Niemcy, Francja) administracja prezydenta zdecydowała się na zaatakowanie Iraku. W rzeczywistości w swoich działaniach rząd amerykański kierował się złożonymi przyczynami. Dla uproszczenia można je podzielić na deklarowane

${ }^{8}$ Trudno równocześnie wyobrazić sobie przypuszczalne skutki niepodjęcia przez prezydenta G. W. Busha działań na Bliskim Wschodzie. Jedna z koncepcji zakłada, że zaangażowanie się Stanów Zjednoczonych w regionie pozwoliło oddalić zagrożenie terroryzmem na ich terytorium i przenieść wojnę z terroryzmem do Iraku i Afganistanu. Stanowisko to mogłoby być potwierdzone zaangażowaniem się Al-kaidy w Iraku. Twierdzenie, że doktryna Busha pozwoliła zatrzymać rozwój globalnego terroryzmu pozostaje jednak kwestią dyskusyjną i wykracza poza główny wątek rozważań.

${ }^{9}$ W trakcie operacji „Pustynny Lis” dokonano w grudniu 1998 r. ataków z morza i z powietrza na terytorium Iraku przez połączone siły amerykańsko-brytyjskie. Głównym celem było osłabienie zdolności Iraku do produkcji broni masowego rażenia. Oficjalnym powodem nalotów było utrudnianie przez Irak prac inspektorów rozbrojeniowych z ze Specjalnej Komisji ONZ - UNSCOM. Operacja stanowiła potwierdzenie, że Stany Zjednoczone podejmą zdecydowane kroki celem uniemożliwienia Irakowi uzyskania broni masowego rażenia. 
i niedeklarowane ${ }^{10}$. Taki podział sugeruje, że deklarowane przyczyny nie były do końca trafione i wymagają wyjaśnienia.

Do głównych deklarowanych przyczyn można zaliczyć:

- powiązania Saddama Husajna z terrorystami,

- posiadanie przez Irak broni masowego rażenia,

- łamanie przez Irak praw człowieka,

- konieczność demokratyzacji Iraku.

Broni masowego rażenia, o której posiadanie oskarżano rząd Saddama Husajna nie znaleziono. Opublikowany w 2004 r. raport przygotowany pod kierownictwem inspektora Charlesa Duelfera na zlecenie CIA potwierdził, że w Iraku nie znaleziono broni masowego rażenia (DCI Special).Wskazywano jedynie, iż rząd iracki rozważał wznowienie prac nad jej pozyskaniem. Tym samym raport wykluczył jeden z głównych argumentów, jakim posługiwano się uzasadniając inwazję na Irak. Mówiąc o broni chemicznej wypada zaznaczyć, że Stephen Walt i John Mearsheimer odnotowali fakt, że szef gabinetu wiceprezydenta Richarda B. Cheneya Lewis „Scooter” Libby jeszcze przed inwazją naciskał na CIA celem przygotowania raportu uzasadniającego wojnę w Iraku (Mearsheimer, Walt, 2007, s. 250-251) ${ }^{11}$. Stanowisko to zdają się potwierdzać inne źródła. Były szef departamentu ds. walki z terroryzmem Richard A. Clark, wspominać miał nawet, że już 12 września $2001 \mathrm{r}$. pojawiły się bezpośrednie naciski ze strony prezydenta na szukanie związków między porwaniem samolotów a Irakiem (Tanner, 2007 s. 195-196). Sam Colin Powell po wielu latach przyznał, że tezy zawarte w przemówieniu z 5 lutego $2003 \mathrm{r}$. na forum ONZ były zmyślone. W swoim słynnym przemówieniu sekretarz stanu ogłosił, że dyplomatyczne metody nie pomogły doprowadzić do pozbawienia Iraku broni chemicznej i wskazywał na konieczność zbrojnej interwencji (US secretary). Fakt, iż już w 2004 r. wykluczono posiadanie broni chemicznej przez Irak doprowadził do przekształcenia misji. Miejsce oskarżeń o posiadanie broni masowego rażenia zastąpiły te, w których wskazywano na łamanie praw człowieka i konieczność demokratyzacji Iraku. Dwa główne argumenty, a więc terroryzm i broń masowego rażenia zostały wówczas podważone. Z ustaleń „New York Times” wynika jednak, iż w momencie ataku na Irak, na jego teryto-

${ }^{10} \mathrm{~W}$ literaturze spotyka się także podział na przyczyn deklarowane i rzeczywiste (np. Świętek, 2011).

${ }^{11}$ Co zastanawiające L. Libby był w młodości studentem nastawionego szczególnie antyiracko Paula Wolfowitza. Analiza materiałów nie pozostawia żadnych wątpliwości, że w dalszym ciągu pozostawał on pod silnym wpływem P. Wolfowitza. 
rium znajdowała się broń chemiczna wyprodukowana przed $1991 \mathrm{r}$. (Chivers, 2014). Istnieją jednak podejrzenia, że została ona wyprodukowana dzięki pomocy z USA i Europy. Wojsko amerykańskie miało likwidować broń w sekrecie (Zawadzki, 2016). Problem ten wymaga jednak przeprowadzenia bardziej szczegółowego wyjaśnienia.

Odwołania do demokracji i praw człowieka dość często pojawiały się w wystąpieniach prezydenta G. W. Busha. Można stwierdzić, iż te ideały prezydentowi Stanów Zjednoczonych były rzeczywiście bliskie. Problematyczna pozostaje jednak ich wiarygodność. Wypada zaznaczyć, że Stany Zjednoczone odmawiały interweniowania tam, gdzie prawa człowieka były regularnie łamane w stopniu o wiele większym niż w Iraku. Co więcej, łamanie praw człowieka przez partnerów strategicznych Stanów Zjednoczonych nie tylko nie stanowiło pretekstu do interwencji w sprawy wewnętrzne, ale nawet nigdy nie stało na przeszkodzie ścisłej współpracy. Również kwestia demokratyzacji budzi poważne zastrzeżenia. Stany Zjednoczone wielokrotnie w swojej historii wspierały rządy niedemokratyczne. Poza tym idea przeniesienia na grunt kultury arabskiej systemów demokratycznych rodziła wątpliwości. Liczne doświadczenia pokazują, że demokracja wprowadzana przy użyciu interwencji wojskowej jest trudna do utrzymania. Pod tym względem interwencja USA musiała ponieść porażkę.

Główne niedeklarowane (przypuszczalne) przyczyny koncentrują się wokół trzech problemów:

- kontrola irackich złóż ropy naftowej

- Irak był najłatwiejszym do pokonania pod względem wojskowym przeciwnikiem z osi zła

- $\quad$ wpływ proizraelskiego lobby

Analizując literaturę przedmiotu można zauważyć, iż najczęściej występującą przyczyną wojny w Iraku pozostają zasoby ropy naftowej Iraku. Irak nie dysponuje co prawda tak znaczącymi złożami jak np. Arabia Saudyjska, niemniej wielkość ich rezerw w dalszym ciągu jest szacowana na prawie 9\% światowych zasobów (BP statistical, 2015). Można zatem przyjąć, iż ustanowienie na terytorium Iraku proamerykańskiej władzy umożliwiłoby Stanom Zjednoczonym kontrolowanie irackich złóż. Z drugiej jednak strony, w opinii części autorów ten argument nie był decydujący (Świętek, 2011, s. 150).

Interesujące wnioski wysunęli J. Mearsheimer i S. Walt. Autorzy wskazywali na wpływ środowisk proizraelskich na politykę zagranicz- 
ną USA ${ }^{12}$. W administracji prezydenta znajdowało się liczne grono proizraelskich polityków, jak chociażby wicesekretarz obrony Paul Wolfowitz - późniejszy szef Banku Światowego. Swoich proizraelskich sympatii nie ukrywali również stojący wyżej w hierarchii wiceprezydent Richard Cheney, czy też szef departamentu obrony Donald Rumsfeld. Zdaniem autorów, wpływ Izraela na politykę zagraniczną prezydenta G. W. Busha był tak silny, że sugerowano nawet bezpośredni atak na Iran, stanowiący większe zagrożenie dla bezpieczeństwa Izraela. Dużą aktywność w okresie poprzedzającym wojnę w Iraku wykazywał izraelski premier Ariel Szaron. W 2002 w wywiadzie przeprowadzonym dla brytyjskiego dziennika „The Times” nazwał Iran centrum światowego terroryzmu (Mearsheimer, Walt, 2007, s. 291-292). Determinacją lobby izraelskiego tłumaczy tutaj politykę bezpieczeństwa Izraela. Iran stanowił wówczas znacznie większe zagrożenie niż Irak.

Godne uwagi przemyślenia przedstawił cytowany już S. Tanner. W jego ocenie prezydent dążył do konfrontacji z jednym z państw z tzw. osi zła. Pokonanie Iranu, państwa większego zarówno terytorialnie jak i demograficznie od Iraku wiązałoby się z niewspółmiernie wysokimi kosztami. Również atak na Koreę Północną został wykluczony. Państwo to deklarowało, że dysponuje bronią masowego rażenia i w tym kontekście amerykańska interwencja byłaby uzasadniona w większym stopniu niż wojna w Iraku. Głównymi przeszkodami były jednak charakter armii północnokoreańskiej oraz mniejsze znaczenie strategiczne. Zdaniem autora właśnie to przeważyło, że najbardziej opłacalnym i zarazem najłatwiejszym celem pozostawał właśnie Irak (Tanner, 2007, s. 195-220).

Warto wskazać również na inne, przypuszczalne przyczyny amerykańskiej interwencji. Wydaje się, iż jednym z decydujących czynników mógł tu być charakter amerykańskich elit politycznych, skupionych wokół administracji G. W. Busha. Wspominano już o proizraelskim nastawieniu części z nich, niektórzy politycy mieli opinię ,jastrzębi”, np. R. Cheney, D. Rumsfeld, R. Perle i P. Wolfowitz. Poglądy tego środowiska cieszyły się uznaniem wpływowych neokonserwatywnych publicystów takich jak Rober Kagan, czy też Charles Krauthammer ${ }^{13}$.

${ }^{12}$ Wpływ na decyzję o zaangażowaniu się USA w Iraku mogło mieć także lobby saudyjskie (Świętek, 2011, s. 190).

${ }^{13}$ Opublikowany w 2002 r. roku w „Policy Review” artykuł Roberta Kagana Power and weakness doskonale oddaje stanowisko neokonserwatystów i atmosferę jaka panowała bezpośrednio przed inwazją na Irak. Autor posłużył się sformułowaniem „Amerykanie są z Marsa, Europejczycy są z Wenus”. Ta analogia wyjaśnia stosunek do potęgi 
Warto również zaznaczyć, że początkowo społeczeństwo amerykańskie aprobowało bojowe nastawienie prezydenta. Nastroje zaczęły się zmieniać wraz ze wzrostem ofiar i odczuwalnych kosztów wojny. Notowania prezydenta wzrosły po schwytaniu Saddama Husajna. $\mathrm{Z}$ perspektywy same operacji miało to znaczenie tylko symboliczne, niemniej pozwoliło G. W. Bushowi skutecznie powalczyć o drugą kadencję.

\section{SKUTKI II WOJNY W IRAKU}

WOJNA W IRAKU POZOSTAJE JEDNYM Z NAJWIĘKSZYCH KONFLIKTÓW XXI WIEKU. Jej ogólny bilans powinien uwzględniać nie tylko czynniki materialne. Bardziej przerażający obraz nasuwa liczba ofiar śmiertelnych, zwłaszcza wśród ludności cywilnej. Z perspektywy czasu można zatem uznać, iż interwencja w Iraku okazała się bardzo kosztowna, zarówno w wymiarze ludzkim, jak i materialnym. Powody deklarowane przez rząd amerykański znacznie różniły się od rzeczywistych. Zagrożenia zdefiniowane w doktrynie Busha nie były trafne, można odnieść wrażenie, że przeceniono zarówno potencjał militarny Iraku, jak i zagrożenie z jego strony. Wykazano, iż w momencie amerykańskiej inwazji nie dysponowano rzetelnymi danymi na temat posiadania przez Irak broni chemicznej, a coraz więcej przesłanek świadczy o tym, że służyła ona jedynie administracji amerykańskiej do przekonania Amerykanów i społeczności międzynarodowej o słuszności interwencji. Wojna negatywnie wpłynęła na wizerunek Stanów Zjednoczonych na świecie, osłabiając oddziaływanie ich miękkiej siły ${ }^{14}$. Powszechnie oskarżano je o egoizm, unilateralizm, jednak wskazywano również na nadmierne eksponowanie siły militarnej i arogancję.

Można również przyjąć założenie, że skutki interwencji odczuwalne są do dnia dzisiejszego. Po pierwsze Irak pozostaje państwem upadłym. Odbudowa gospodarki i infrastruktury państwa jest procesem długotrwałym, wymagającym gigantycznych nakładów finansowych. Po drugie społeczeństwo irackie jest mocno podzielone, na skutek in-

militarnej i dyplomatycznych form realizacji interesów narodowych. Europejczycy odeszli od stosowania siły militarnej na rzec prawa międzynarodowego oraz międzynarodowej współpracy i negocjacji, z kolei dla Amerykanów o ich pozycji na świecie decydowały możliwości militarne. Ten wyraźny rozdźwięk w świecie transatlantyckim miał wynikać z różnic na tle postrzegania rzeczywistości międzynarodowej. (Kagan, 2002, s. 3).

${ }^{14}$ Sposób w jaki polityka zagraniczna prezydenta G. W. Busha wpłynęła na postrzeganie USA w świecie wyczerpująco przedstawił Joseph S. Nye jr w pracy poświęconej miękkiej sile (Nye, 2004). 
terwencji odżyły tradycyjne uprzedzenia między szyitami a sunnitami. Zbiegają się z tym aspiracje niepodległościowe mniejszości kurdyjskiej. Po trzecie trudno mówić o odbudowie w warunkach stałego chaosu. Jednym z następstw wycofania wojsk amerykańskich z Iraku jest stan wojny domowej. Władze Iraku nie są zdolne do kontrolowania terytorium całego państwa. Obecnie jednym z największych zagrożeń dla ludności i władzy Iraku pozostaje tzw. Państwo Islamskie (arab. Daesh, skrót od Państwo Islamskie w Iraku i Syrii) - samozwańczy kalifat działający na terytorium Iraku i Syrii. Pomimo dość ograniczonych zasobów kontroluje on prawie jedną trzecią powierzchni Iraku, skutecznie paraliżując cale państwo. Innym następstwem pozostaje umocnienie się Iranu, jako mocarstwa regionalnego. Iran, traktowany nieufnie przez Stany Zjednoczone na wojnie w Iraku zyskał co najmniej na dwa sposoby. Po pierwsze stracił przeciwwagę w postaci silnego sąsiada, po drugie przewodzącą grupą religijną stali się szyici - wyznawcy tego samego odłamu islamu, co mieszkańcy Iranu. Wydaje się również, że obalenie S. Husajna stanowiło inspirację dla tzw. arabskiej wiosny, w której doszło do masowych przemian politycznych na Bliskim Wschodzie. Wbrew wcześniejszym oczekiwaniom proces ten nie doprowadził do demokratyzacji regionu. Można nawet przyjąć, iż jednym z jego skutków jest radykalizacja postaw muzułmanów.

\section{Podsumowanie}

W pracy podkreślono wyraźny związek między wojną w Iraku, a doktryną Busha, zaakcentowano różne przyczyny wojny wskazując, że te rzeczywiste nie zawsze pokrywały się w pełni z deklarowanymi. Podkreślono również konsekwencje realizacji doktryny Busha, wskazując na ofiary ludzkie i straty materialne. Wykazano także silny związek między wojną w Iraku, a postrzeganiem globalnej roli Stanów Zjednoczonych, które uległo pogorszeniu na skutek zaangażowania militarnego w Iraku.

Analiza skutków doktryny G. W. Busha względem Iraku prowadzi do mało optymistycznych wniosków. Pomimo zakładanego w niej idealizmu i optymizmu region Bliskiego Wschodu okazał się nie tylko zamknięty na zachodnie wartości, ale Stany Zjednoczone naraziły się na krytykę zwłaszcza społeczności muzułmańskiej. Porównując interwencję z roku 2003 z wojną z 1991 r. zauważalne są widoczne różnice, które przesądziły o sukcesie tej pierwszej i o porażce drugiej. W przypadku I wojny w Iraku udało się zmontować szeroką koalicję, składającą się również z państw arabskich, a sama interwencja miała 
mandat Organizacji Narodów Zjednoczonych. W 1991 r. nie pojawiła się tak wyrazista retoryka jak w $2001 \mathrm{r}$ i wypowiedzi takie jak „albo jesteście z nami albo jesteście z terrorystami” nie miały miejsca. Wręcz przeciwnie, Stany Zjednoczone stawiały na multilateralizm, budując aprobatę dla swojej polityki zagranicznej. Poza tym posiadły wówczas przemyślaną strategię rozgrywania konfliktu; określono cele, które konsekwentnie realizowano. W przypadku II wojny te elementy pominięto i skupiono się na obronie amerykańskich interesów z pominięciem opinii społeczności międzynarodowej oraz otwarcie wystąpiono przeciw prawu międzynarodowemu. W dodatku można odnieść wrażenie, że administracji G. W. Busha brakowało pomysłu na rozgrywanie konfliktu, a sama próba przeniesienia demokracji na ziemie leżące nad Eufratem i Tygrysem okazała się bardzo kosztowna.

\section{BIBLIOGRAFIA}

BP Statistical Review of World Energy, June 2015, http://www.bp.com/ content/dam/bp/pdf/energy-economics/statistical-review-2015/bpstatistical-review-of-world-energy-2015-full-report.pdf, 10.01.2016 r.

Brzeziński Z. Druga szansa, Warszawa 2008.

Chivers C. J. The Secret Casualties of Iraq's Abandoned Chemical Weapons, http://www.nytimes.com/interactive/2014/10/14/world/middleeast/us-casualties-of-iraq-chemical-weapons.html, 3.02.2016.

DCI Special Advisor Report on Iraq's WMD, https://www.cia.gov/library/reports/general-reports-1/iraq_wmd_2004/index.html, 11.01.2016.

Dwight D. Eisenhower, Special Message to the Congress on the Situation in the Middle East, January 5, 1957, http://www.presidency.ucsb.edu/ws/index.php?pid=11007\&st=\&st1 $=, 15.01 .2016$.

Dzielski W. Idealizm George'a Busha a II wojna w Zatoce Perskiej, [w]: Irak. Dylematy amerykańskiej interwencji, red. W. Dzielski, W. Michnik, Kraków 2007.

Bush G. W. 9/11 Address to the Nation, http://www.americanrhetoric.com/ speeches/gwbush911addresstothenation.htm, 11.01.2016.

Bush G. W. Commencement Address at the United States Military Academy at West Point, West Point, New York, June 1, 2002, http://www.presidentialrhetoric.com/speeches/o6.01.02.html, 11.01.2016.

Bush G. W. Remarks to the U.N., New York. September 12, 2002, http://www. presidentialrhetoric.com/speeches/09.12.02.html, 19.01.2016.

Bush G. W. State of the Union, Washington, DC, January 29, 2002, http:// www.presidentialrhetoric.com/speeches/01.29.02.html,11.01.2011. 
Bush G. W. The Farewell Address, Washington, D.C., January 15, 2009, http:// www.presidentialrhetoric.com/speeches/01.15.09.html, 19.01.2016.

Guzik J. Bush broni wojny w Iraku, http://www.rp.pl/artykul/229663-Bush-broni-wojny-w-Iraku.html\#ap-2, 11.07.2016.

Iraq body count, https://www.iraqbodycount.org/, 31.01.2016.

Jimmy Carter, The State of the Union Address Delivered Before a Joint Session of the Congress, January 23, 1980, http://www.presidency.ucsb.edu/ ws/index.php?pid=33079, 12.01.2016 r.

Kagan R. Power and weakness, „Policy Review” No. 113, June \& July 2002.

Kiwerska J. Strategia Bezpieczeństwa Narodowego USA, „Biuletyn Instytutu Zachodniego", Nr 40/2010, http://www.iz.poznan.pl/news/206_nr\%20 40.\%20Strategia\%2obezpiecze\%C5\%84stwa\%2onarodowego\%2oUSA. pdf, 5.01. 2011.

Kiwerska J., The United States in the World of Diversified Powers, „Przegląd Zachodni”, 2013, No 2.

Malendowski W. „Trwała Wolność”(Enduring Freedom) Interwencja zbrojna w Afganistanie - pierwsza wojna XXI wieku, [w:] Spory - konflikty zbrojne - terroryzm. Dysfunkcjonalne czynniki współczesnych stosunków międzynarodowych, red. W. Malendowski, Poznań 2006.

Mearsheimer J. ,Walt S. The Israel lobby and US foreign policy, New York, 2007.

Michnik W. Długa droga do wojny - USA i przyczyny II wojny w Zatoce Perskiej, [w]: Irak. Dylematy amerykańskiej interwencji, red. W. Dzielski,

W. Michnik, Kraków 2007.

Nye J. S. Soft Power. Jak osiągnąć sukces w polityce światowej, Warszawa 2007.

Przemówienie Georga W. Busha po atakach terrorystycznych z 11 września 2001 roku - 20 września 2001 r., http://www.stosunki-miedzynarodowe. $\mathrm{pl} /$, 18.03.2011.

Rathmell A., Karasik T., Gompert D. A New Persian Gulf Security System, https://www.rand.org/content/dam/rand/pubs/issue_papers/2005/ IP248.pdf, 10.07.2016.

Stiglitz J. E., Bilmes L. J. Wojna za trzy biliony dolarów. Prawdziwy koszt konfliktu w Iraku, Warszawa 2010.

Świętek H. Wojna z Irakiem w 2003 roku. Główne przyczyny, Warszawa 2011. Szymborski W. Doktryna Busha, Bydgoszcz 2004.

Tanner S. Wojny Bushów. Ojciec i syn jako zwierzchnicy sił zbrojnych, Wrocław 2007.

The National Security Strategy of the United States of America, March 2006 
The National Security Strategy of the United States of America, September 2002.

Troszyńska M. Polityka zagraniczna Stanów Zjednoczonych w latach 2000 -2004, Toruń 2006.

US expands ,axis of evil', http://news.bbc.co.uk/2/hi/americas/1971852.stm, 11.07.2002.

US secretary of state's address to the United Nations security council, http:// www.theguardian.com/world/2003/feb/o5/iraq.usa, 15.01.2016.

Zawadzki M. Amerykanie zataili znalezienie w Iraku składów broni chemicznej, http://wyborcza.pl/1,76842,16812671,Amerykanie_zataili_znalezienie_w_Iraku_skladow_broni.html, 3.02.2016.

\section{SUMMARY}

The article presents changes in American foreign policy after 11th 2001 and is concerned the George W. Bush's Middle East policy. The goal of the text is presenting how the Bush doctrine leaded to war in Iraq. After the short introduction about US Middle East policy the text explains fundamental parts of doctrine and describes the most important G. W. Bush speeches and National Security Strategies from 2002 and 2006. This part is dedicated on war on terror, axis of evil and preventive war. The next part try to identify actual and the official and publically stated causes the 2003 invasion of Iraq. The article ends with the analysis the cost of Iraq war.

\section{Nota o Autorze}

Piotr Kaczmarek - [kaczmarekptr@gmail.com] doktorant w Zakładzie Stosunków Międzynarodowych WNPiD UAM, Stypendysta Ministra Nauki i Szkolnictwa Wyższego 2011/2012, członek Polskiego Towarzystwa Nauk Politycznych i Polskiego Towarzystwa Studiów Międzynarodowych. Jego zainteresowania koncentrują się wokół rywalizacji mocarstw, polityki zagranicznej Stanów Zjednoczonych i Chińskiej Republiki Ludowej. 
